\title{
Faktor yang Dipertimbangkan Buyer dalam Keputusan Pembelian Hasil Laut Olahan Produksi Indonesia
}

\author{
Erna Ferrinadewi, Martinus Rukismono \\ Universitas Widya Kartika Surabaya \\ e-mail: ferrinadewi@gmail.com
}

\begin{abstract}
Considering Indonesia's marine goods has big potential and world's fish consumption per capita which is $20 \mathrm{kgs}$ per year, we should be able to utilize it maximally. It will become biggest contribution to Indonesia' economy as maritime country. However, in reality Indonesia marine goods export tends to decrease $3.25 \%$ since 2014 and marine export contribution to PDB so far is no more than 30\%. UKM face problem in expanding market area and competition in international marine goods processed where Thailand and Vietnam has more competitive price. This objective of this research is identifying what consideration factors of international buyer in their decision to buy Indonesia marine goods. It involves 10 buyers of Gulama bubbles, Snapper bubbles, Manyung bubbles and Kurau bubbles. Data gathered through depth interview with respondent personally and later on describes and analyses deeper. The result of analysis is researcher able to identify a number of consideration factors used by buyer in their decision to buy fish bubbles and sea cucumber which are colour, freshness, fish type, moistures, hygiene factors and sales service speed.
\end{abstract}

Keywords: purchase decision, consumer behaviour, product of the sea

\section{Pendahuluan}

Indonesia adalah negara maritim dengan garis pantai terpanjang kedua setelah Kanada yaitu $55.000 \mathrm{~km}$ dan di antara dua samudra, yaitu Samudra Hindia dan Samudra Pasifik serta merupakan negara kepulauan $1.904 .000 \mathrm{~m}^{2}$ tentunya memiliki potensi perairan yang tidak sedikit. Jumlah tangkapan ikan di Indonesia mencapai 5.4 juta per tahun. Menurut Indonesia Maritime Institute (IMI) potensi laut Indonesia mencapai enam kali lipat dari Anggaran Pendapatan dan Belanja Negara (APBN). Namun, meskipun Indonesia merupakan negara yang kaya laut, tapi potensi kelautannya belum dimanfaatkan secara maksimal (https://www.hrcindonesia.org/ potensi-laut-indonesia-senilai-7200-tri).

Berdasarkan data Badan Pusat Statistik (BPS), pada Januari-Oktober 2017 ekspor produk perikanan Indonesia hanya 862,1 ribu ton, jumlah lebih kecil dari periode yang sama tahun sebelumnya. Pencapaian ekspor tahun 2015 yang mencapai 1,1 juta ton dan 2014 yang menyentuh angka 1,3 juta ton. Tahun 2024 mendatang, Food Agriculture Organization (FAO) menyebut potensi pasar produk perikanan global mencapai 240 juta ton per tahun dan Indonesia berpotensi menguasai 25 persen dari potensi global. Potensi laut Indonesia belum maksimal dimanfaatkan bahkan cenderung menurun nilai ekspor hasil laut Indonesia dari tahun ke tahun (https://www.aa.com.tr/ id/ekonomi/kadin-pemanfaatan-potensi-laut-indonesia-belum-maksimal/1027120).

Sementara kebutuhan konsumsi ikan per kapita di dunia rata-rata mencapai 9,9 kg per tahun. Angka konsumsi rata-rata perkapita ini menurut organisasi Food and Agriculture (FAO) meningkat menjadi $14,4 \mathrm{~kg}$ per tahun pada tahun 1990-an dan tahun 2009 rata-rata konsumsi perkapita meningkat menjadi $18,1 \mathrm{~kg}$. Tahun 2014 konsumsi hasil laut rata-rata perkapita telah mencapai $20 \mathrm{~kg}$ per tahun. Angka ini menunjukkan tingginya kebutuhan akan konsumsi 


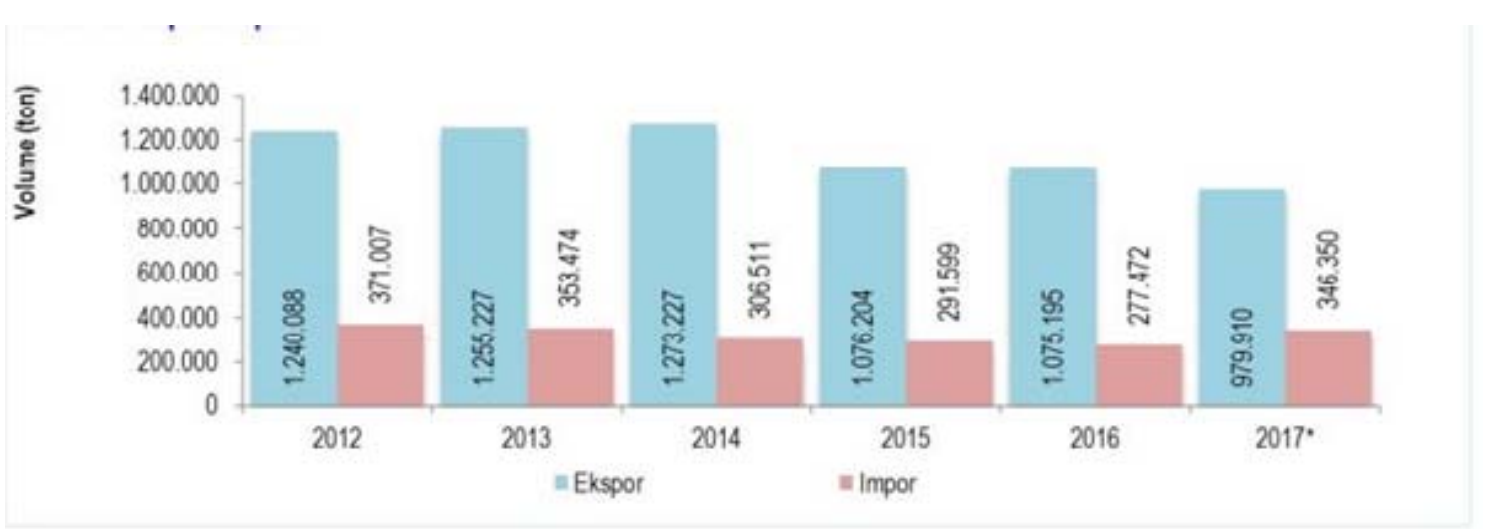

Volume Ekspor Impor Perikanan Indonesia Tahun 2012-2017

ikan laut sebagai sumber protein, asam lemak omega 3, vitamin, kalsium, dan zat besi. Namun data menyebutkan penurunan angka ekspor produk hasil laut sejak tahun 2014.

Berdasarkan data Dirjen Penguatan Daya Saing Produk Kelautan dan Perikanan (KKP) terjadi penurunan nilai ekspor sebesar 3.25\% namun demikian nilai ekspor mengalami kenaikan tren yang signifikan untuk negara tujuan Cina, Asean, dan Uni Eropa. Peningkatan tertinggi ekspor adalah Negara Cina mencapai 10.25\% berdasarkan data Dirjen KKP.

Negara Cina merupakan negara dengan permintaan impor makanan laut yang terus meningkat signifikan dari tahun 2009 dan diperkirakan hingga tahun 2020, permintaan impor makanan laut di Negara Cina akan meningkat lebih dari US\$20 juta dari seluruh negara di dunia (a report by Caplog Group, with the support of EDF Mexico, 2014).

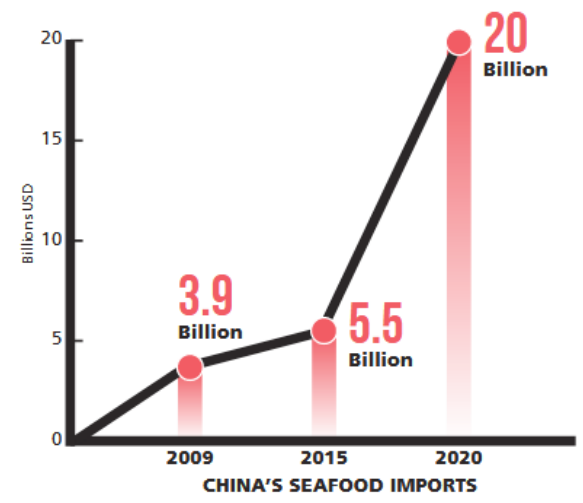

Hal ini merupakan kesempatan emas bagi industri makanan laut khususnya gelembung perut ikan, namun sangat disayangkan ketika potensi kelautan Indonesia ini belum dimanfaatkan secara maksimal. Hasil laut dapat berkontribusi secara signifikan terhadap perekonomian Indonesia. Letak geografis Indonesia dan panjangnya garis pantai serta kenyataan bahwa Indonesia adalah negara kepulauan dengan 2/3 wilayahnya berupa laut seharusnya potensi ekonomi Indonesia sektor kelautan melebihi Negara Thailand bahkan Jepang dan diperkirakan mampu menyerap 40 juta tenaga kerja. Kenyataannya kontribusi ekonomi sektor kelautan Indonesia masih di bawah 30\% terhadap PDB nasional.

Maka langkah yang tepat ketika pemerintah era Jokowi ini memiliki kebijakan kelautan yang bercita-cita Indonesia sebagai Poros Maritim Dunia, dan mampu memberikan manfaat sebesar-besarnya bagi kemakmuran rakyat yang dijabarkan dalam tujuh komponen kebijakan yaitu menumbuhkan budaya maritim, memanfaatkan sebesar-besarnya hasil laut untuk kesejahteraan rakyat, membangun tata ruang dan lingkungan laut yang lebih baik, membangun infrastruktur dan konektivitas antar-pulau, membangun pendidikan dan teknologi tentang kemaritiman, menggalakkan diplomasi maritim, dan keamanan maritim. 
PT Mega Mandiri merupakan UKM yang bergerak di bidang pengolahan hasil laut berupa gelembung perut ikan seperti ikan gulama, ikan kakap, ikan kurau, ikan hipyo, dan teripang. Hingga saat ini buyer UKM ini berasal dari Negara Hongkong, Singapore, dan sedikit dari Negara Cina. Produk UKM ini bersaing dengan Negara Vietnam dan Thailand. Hasil ekspor UKM ini menunjukkan peningkatan dari tahun ke tahun namun UKM ini mengalami kesulitan untuk menambah area pemasaran yang lebih luas di Cina, hal ini sangat disayangkan mengingat Negara Cina merupakan negara dengan tren permintaan yang meningkat dan kesempatan ini diambil oleh eksportir asal Negara Thailand dan Vietnam.

UKM ini bukannya tidak berupaya untuk meningkatkan jumlah permintaan dari Negara Cina salah satunya dengan pemanfaatan website sebagai sarana promosi dan pemasaran online, mengikuti bursa perdagangan ikan di Hongkong untuk mendapatkan buyer baru, promosi, dan mengirimkan sampel secara door to door ke berbagai restauran, berupaya mendapatkan sertifikasi HACCP namun demikian belum ada peningkatan signifikan terhadap jumlah permintaan dari Negara Cina. Jika UKM tidak berupaya mengatasi masalah ini maka tidak menutup kemungkinan bisnis ini akan merugi. Apakah terdapat sejumlah faktor yang dipertimbangkan pembeli dalam keputusan pembelian produk hasil olahan laut asal Indonesia.

\section{Tinjauan Pustaka}

Pembeli akan selalu berusaha memenuhi kebutuhannya dan melakukan pembelian merupakan salah satu jalan keluar yang dipilih memenuhi kebutuhan. Pada dasarnya, kebutuhan konsumen merupakan masalah realitas yang harus diselesaikan dan melakukan keputusan pembelian menjadi alternatif penyelesaiannya. Keputusan pembelian merupakan sebuah proses yang berjalan alami namun selaku diawali dengan adanya kesenjangan antara kenyataan dan kondisi yang diharapkan. Dimulai dari identifikasi masalah kemudian dilanjutkan dengan pencarian informasi untuk selanjutnya informasi tersebut dievaluasi untuk mendapatkan alternatif terbaik sebagai pilihan dalam melakukan pembelian. Sehingga dapat dikatakan bahwa keputusan pembelian merupakan proses yang secara sadar ataupun tidak sadar terjadi dalam benak konsumen (Ferrinadewi, 2008).

Keputusan pembelian menjadi gambaran utama yang mampu menjelaskan perbedaan perilaku konsumen yang satu dengan lain, banyak ahli lain berpendapat bahwa keputusan pembelian meliputi paling sedikit lima aktivitas tersebut termasuk dalam keputusan pembelian produk makanan.

Dalam konteks produk makanan, konsumen menjadi sangat banyak pertimbangan dan hal ini wajar karena produk ini memiliki risiko kesehatan baik jangka panjang maupun jangka pendek. Kandungan makanan seringkali menjadi faktor pertimbangan akan keamanan produk makanan dan kualitas yang diterima konsumen (Chang, Tseng, Chu, 2013). Regulasi Uni Eropa bahkan dengan jelas mengatur komponen traceability sebagai kemampuan produk makanan tersebut untuk ditelusuri dan diikuti kandungan makanan mulai dari proses produksi hingga distribusinya. Dalam produk olahan hasil laut dalam hal ini ikan, seringkali frekuensi dan preferensi konsumen dipengaruhi oleh karakteristik geografi, sosial, dan budaya yang spesifik (Verbeke dan Vackler, 2005). Bahkan pilihan konsumsi ikan konsumen dipengaruhi juga oleh kriteria-kriteria sensorik seperti aroma, tekstur, 
dan rasa juga dipengaruhi oleh kriteria nonsensorik seperti perilaku masyarakat, keyakinan setempat, risiko makanan, dan karakter personal pembeli (Honkanen et al. 2005). Seperti masyarakat Jepang dan Turki yang menyukai konsumsi ikan segar bahkan mentah namun tidak demikian halnya di Indonesia dan Cina.

Produk ikan laut banyak diminati karena tingginya asam amino yang bermanfaat untuk kesehatan tubuh. Demikian juga dengan gelembung ikan laut yang merupakan selaput tipis di antara daging dan perut ikan yang berfungsi membuat ikan mengapung di air. Gelembung ikan laut memiliki kandungan asam amino sebesar $66.2 \%$ inilah sebabnya mengapa gelembung ikan laut banyak digunakan secara luas dalam pengobatan tradisional dan makanan di Asia (Wen, 2016).

Perilaku konsumen merupakan disiplin ilmu yang berasumsi bahwa perusahaan yang ingin sukses dalam berbisnis harus mampu mengidentifikasi kebutuhan konsumen dan keinginan secara spesifik dan berupaya memenuhinya dengan cara yang lebih baik daripada pesaing (Schiffman dan Kanuk, 2005). Perilaku pembeli menjadi lebih kompleks karena dalam keputusan pembelian seringkali konsumen tidak mendasarkan keputusannya pada pertimbangan rasional namun juga dengan pertimbangan emosional psikologisnya.

Menurut Grunert et al. (1995) dalam Bruns (2002) berdasarkan persepsinya konsumen menilai kualitas produk makanan dapat dibedakan menjadi empat tipe kualitas makanan sebagai berikut.

Product-oriented quality merupakan persepsi konsumen yang menilai kualitas produk makanan berdasarkan tampilan fisik yang mampu memberikan deskripsi spesifik tentang produk tersebut seperti misalkan tampilan lemak dan otot pada daging ikan tuna dan kesegaran warna daging ikan.

Process-oriented quality merupakan penilaian konsumen berdasarkan persepsi mereka melihat proses produksi menyeluruh produk makanan misalkan produk susu sapi apakah susu tersebut dihasilkan dari sapi yang diberi makan mengandung pestisida atau telur yang dihasilkan dari ayam yang disuntik hormon tertentu. Konsumen membutuhkan deskripsi prosedur produksi yang dipakai walaupun prosedur tersebut tidak memberikan efek pada perubahan bentuk produk.

Quality control, konsumen dengan sudut pandang ini akan mencari standar produk yang harus dipenuhi untuk mendapatkan standardisasi tertentu misalkan standar kesehatan didasarkan pada kriteria ukuran produk, variasi produk, kandungan produk klasifikasi produk, dan lainnya.

User-oriented quality, persepsi kualitas yang benar-benar hanya didasarkan pada sudut pandang konsumen saja tanpa pertimbangan rasional lainnya yang umum digunakan.

Keempat tipe kualitas produk makanan tersebut akan berkaitan satu sama lain di mana product-oriented quality bersama-sama dengan process-oriented quality dan quality control berinteraksi menjadi objective quality yang akan menciptakan user-oriented quality namun tentu saja ada variabel lain di luar objective quality yang turut memengaruhi user oriented quality seperti masalah harga, merek, dan aspek penjual (Brunso et al., 2002).

\section{Metodologi}

Penelitian ini merupakan penelitian kualitatif yang berupaya untuk mencari sejumlah faktor yang dipertimbangkan pembeli dalam 
keputusan pembelian produk gelembung perut ikan produksi UKM PT Mega Mandiri. Interview mendalam dilakukan dengan 10 pembeli aktif UKM yang telah melakukan pembelian lebih dari sekali. Pembeli berasal dari Hongkong, Singapura, Thailand, dan Cina. Tujuan penelitian ini adalah untuk mendapatkan sejumlah faktor yang dipertimbangkan pembeli dalam keputusan pembelian produk gelembung perut ikan. Buyer atau responden adalah buyer yang membeli dalam jumlah grosir untuk dijual retail di negara masing-masing.

Hasil studi ini akan membantu pelaku UKM yang bergerak di bidang ekspor produksi olahan hasil laut untuk memahami dan mempersiapkan proses produksi yang mampu menghasilkan produk sesuai dengan standar preferensi pembeli internasional.

\section{Hasil dan Pembahasan}

Gelembung perut ikan adalah salah satu bahan tradisional di Cina yang memiliki nilai tinggi karena gelembung perut ikan kaya akan protein dan nutrisi seperti fosfor dan kalsium. Sangat baik dikonsumsi untuk kesehatan ginjal dan menjaga stamina, efektif untuk membantu mengatasi masalah paru-paru, anemia dan lainnya. Termasuk makanan yang cocok dikonsumsi untuk segala usia dan merupakan jenis makanan yang sifatnya therapeutic. Dalam dunia kecantikan, gelembung perut ikan juga sering digunakan karena mengandung bahan yang mampu menjaga kelembaban kulit. Gelembung perut ikan tidak mengandung kolesterol sehingga aman dikonsumsi jangka panjang.

Kualitas gelembung perut ikan ditentukan dari warna, aroma, dan pola kulitnya. Warna gelembung ikan yang berkualitas cenderung kuning dengan tampilan transparan dan kering. Seain itu, kelembabannya kurang dari 10\%.
Kualitas yang tidak stabil menjadi pertimbangan pertama pembeli luar negeri. Standar kualitas dalam produk gelembung ikan memang belum dinyatakan secara resmi dalam ukuran yang dapat diterima semua pembeli. Namun demikian dari hasil wawancara mendalam berhasil diidentifikasi kriteria kualitas terbaik gelembung perut Ikan.

Gelembung perut ikan yang disukai di Bangkok tentunya yang noda putihnya sedikit, meskipun warnanya lebih gelap tidak cerah asalkan noda putih tidak banyak OK lah... gelembung ikan dari Indonesia bagus, tidak banyak noda putihnya. (Buyer 1)

Kami tidak menyukai produk gelembung perut ikan yang ada noda putihnya, itu pasti kita tolak karena tidak ada yang mau membeli produk yang tidak segarkan, dan rasa juga berbeda....

(Buyer 3)

Noda putih pada gelembung perut ikan merupakan tanda tingkat kesegaran produk, semakin banyak warna putih di dalam gelembung menunjukkan produk tersebut telah berkurang kesegarannya. Namun bagi pembeli lain, kesegaran ini merupakan hal mutlak yang dipertimbangkan dalam arti tidak ada noda putih sama sekali. Hal ini dapat dipahami karena gelembung perut ikan merupakan produk dengan banyak manfaat selain untuk dimakan dapat juga digunakan sebagai obat karena itu faktor kesegaran menjadi penting. Kualitas produk makanan laut dinilai berdasarkan tingkat kesegarannya. Kesegaran produk makanan laut merupakan hasil penilaian meliputi tampilan fisik perubahan warna dan tanda-tanda ikan yang cedera atau terluka, meskipun pada umumnya eksportir menilai kesegaran produk makanan laut berdasarkan pengalamannya saja (Karlesen et al., 2015).

“... pelanggan kami banyak yang tidak suka jika warna tidak cerah atau cenderung gelap, seperti 
buah yang segar pasti warnanya juga cerah dan cantik kan...."

(Buyer 4).

“.....warna harus cantik dan cerah. Gelap tidak cantik... tidak segar... dimasak pun tidak enak rasanya... kita terima harus warna bagus, kurang bagus ya susah ditawarkan kembali di sini (Hongkong)".

(Buyer 2).

Tampilan produk merupakan hal pertama yang dilihat oleh calon pembeli terutama untuk produk makanan yang tidak saja dinilai dari soal rasa namun juga dinilai dari presentasi di hadapan pembeli. Warna yang kurang menarik akan menimbulkan persepsi di benak konsumen akan rasa yang tidak enak karena warna merupakan salah satu stimuli yang mampu menciptakan persepsi yang berbeda antar-satu konsumen dengan lainnya (Schiffman dan Kanuk, 2012). Tampilan warna juga sering digunakan oleh pembeli sebagai indikator kesegaran produk dan kualitas rasa (Barrett et al., 2010). Pembeli grosir gelembung perut ikan lebih menyukai warna yang kuning cerah atau pucat daripada warna yang lebih gelap. Namun bagi pembeli retail warna yang gelap lebih menarik karena semakin gelap warnanya, gelembung ikan tersebut makin elastis ketika diproses menjadi makanan.

Dikaitkan dengan masalah harga, kelembaban produk menjadi pertimbangan utama beberapa buyer. Kelembaban akan menentukan besaran berat yang akan dijadikan dasar dalam penentuan harga jual. Jika terlalu kering, produk akan ditimbang semakin ringan dan pada akhirnya harga pun menjadi terlalu murah bagi penjual. Sebaliknya jika terlalu lembab tentu timbangan menjadi lebih berat dan bagi pembeli akan merugi jika hendak dijual kembali. Pemberi berkesimpulan bahwa dalam produk makanan seperti gelembung ikan ini faktor kelembaban menggambarkan kualitas yang diterima dengan harga yang dibayar.

“... harus menguntungkanlah. Terlalu lembab, kami rugi jika dijual kembali karena gelembung akan menyusut terus. Kita harus cepat deal urusan harga...."

(buyer 7).

"Ini produk makanan yang tak tahan lama... jadi gampang susut dan kami rugilah jika membeli kondisi terlalu lembab... di perjalanan ekspedisi gimana itu...?”

(Buyer 6).

“... susah kami kalau produk terlalu lembab, rugi jika kita jual kembali ke restoran di sini karena di jalan sudah susut juga...”

(buyer 8).

Karakter utama gelembung perut ikan adalah mudah menyusut karena kandungan airnya menguap mengering seiring waktu. Semakin panas suhu udara, gelembung perut ikan akan cenderung cepat menyusut beratnya karena kandungan airnya berkurang. UKM menyimpan gelembung ikan gulama dan kace lemari pendingin dengan tujuan menjaga berat yang memberikan keuntungan kedua belah pihak. Penyimpanan di lemari pendingin memang tidak dianjurkan karena menyimpan produk hasil laut di penyimpanan dingin cenderung merusak tekstur produk. Penyimpanan di ruang atau lemari pendingin lebih dari tujuh hari menyebabkan perubahan pada dan size produk yang penyusutan pada berat produk (Sharifian S., et al., 2011). Oleh karena itu, UKM hanya menyimpan gelembung perut ikan di lemari pendingin maksimal dua hari dengan tujuan mempertahankan berat produk sebelum melakukan pengiriman produk.

Tawar menawar harga menjadi makin penting ketika dalam ekspedisi suhu udara tidak dapat dikendalikan untuk menjaga kelembaban pada produk. Tahapan yang seringkali lalai diperhatikan adalah kondisi antara sebelum dan sesu- 
dah produk dimuat di ekspedisi udara padahal temperatur yang tidak dapat dikendalikan akan memengaruhi temperatur produk dan kualitas (Lauzon et al., 2010) sehingga pemilihan moda transportasi utama adalah jalur udara meskipun suhu temperatur sulit dikendalikan namun durasi pengangkutannya yang relatif singkat dibandingkan moda transportasi laut.

Menjaga kelembaban dan mencegah perubahan tekstur yang tujuan utamanya adalah menjaga berat produk saat dikirim dan diterima menjadi tujuan utama dalam proses pengepakan produk olahan hasil laut. Semua pembeli UKM ini sepakat bahwa pengepakan harus dilakukan untuk memastikan produk mereka terima dalam kondisi baik sesuai dengan permintaan sebelumnya. UKM ini melakukan pengepakan dengan beberapa tahap yang dimulai dengan pengepakan dalam karung dilanjutkan dengan pembungkusan karung dengan plastik tebal tertutup kedap udara dan selanjutnya dimasukkan ke dalam kardus tebal sebelum dikirim melalui kargo pesawat. Cara packing ini terbukti mampu menjaga produk sesuai dengan permintaan pembeli. Metode pengepakan memang memengaruhi tekstur produk dan beratnya. Fuentes (2012) membuktikan bahwa pengepakan kedap udara secara nyata mampu mengurangi perubahan tekstur selama proses pengiriman karena kondisi kedap udara mencegah terjadinya efek kelembaban akibat perubahan suhu udara selama pengiriman.

Unsur saling percaya (trust) menjadi faktor lain yang muncul dalam proses negosiasi harga karena produk dikirim ke negara tujuan memerlukan waktu 3-4 hari kerja dengan pesawat udara sudah dapat dipastikan akan terjadi penyusutan. Unsur percaya bahwa penjual akan memberikan yang terbaik kepada konsumen menjadi titik kritis sukses tidaknya kesepakatan soal harga per kilogram. Pencatatan dokumen tentang kondisi pro- duk saat dikirim harus sepengetahuan pembeli sebagai penerima. Bahwa pembeli percaya akan iktikad baik penjual, bahwa penjual akan memberikan informasi akurat tentang berat produk saat dikirim sudah sesuai dengan kesepakatan harga. Unsur kepercayaan menjadi hal penting kesuksesan transaksi penjualan karena adanya jaminan bahwa penjual akan membantu kesulitan pembeli dan penjual memiliki iktikad baik dalam melayani pembeli (Ferrinadewi, 2008).

“... saling percaya... informasi berat produk kan bisa lewat WA berupa foto... ya itu saja sudah cukup buat kita ... kita dagang kan ga boleh rugi, jadi ya haruslah saling percaya”.

(buyer 5).

Dari segi aroma produk, semua buyer sepakat merupakan hal yang penting karena sering beredar produk gelembung ikan palsu. Buyer sepakat aroma gelembung ikan laut yang baik adalah beraroma kuat air asin atau air laut sesuai asal ikan gulama dan ikan Kakap yang hidup di perairan laut dalam. Seluruh buyer sepakat bahwa aroma gelembung perut ikan akan merujuk pada rasa produk itu ketika dimasak. Secara empiris hal ini dapat dijelaskan di mana interaksi antara taste dan aroma akan menciptakan cita rasa makanan karena ada asosiasi antara rasa dan aroma (Costell et al. 2010).

\section{Kesimpulan}

Dapat disimpulkan dalam penawaran produk hasil laut, UKM harus memperhatikan kesegaran produk yang ditandai dengan warna, aroma, dan pola kulit yang cerah, segar, dan berpola tanpa noda. Masalah kebersihan proses produksi juga diutamakan oleh semua pembeli terutama karena beberapa negara tujuan ekspor telah menetapkan standar dasar produk hasil laut yang dapat diterima. 
Hal baru yang mengemuka adalah faktor kepercayaan antara pembeli dan penjual selama proses transaksi karena karakteristik produk hasil laut dalam konteks ini adalah gelembung perut ikan yang mudah mengalami perubahan berat akibat kondisi lingkungan selama proses pengiriman. Ini membutuhkan relasi penjual dan pembeli yang dilandasi oleh keyakinan bahwa masing-masing pihak bertindak jujur.

\section{Daftar Rujukan}

Barrett, Diane M., Beaulieu, John C., dan Shewfelt, Rob. 2010. Color, Flavor, Texture, and Nutritional Quality of FreshCut Fruits and Vegetables: Desirable Levels Instrumental and Sensory Measurement, and the Effects of Processing. Critical Reviews in Food and Nutrition (50) p. 369-389.

Brunso, Karen Fjord, Thomas Ale, Grunert, Klaus G. 2002. Working Paper, No. 77. The Aarhus School of Business.

Costell, E. Tarrega, A. \& Bayyari, S. 2010. Food Acceptance: The Role of Consumer Perception an Attitudes. Chemonsensory Perception, 3(1), pp. 42-50.

Chang A., Tseng, C. And Chu, M. 2013 Value Creation from Food Traceability System based on Hierarchical Model of Consumer Personality Traits. British Food Journal, Vol. 115 pp. 1361-1380.

Cheng, Jun-Hum Sun, Da-Wen, Zhong Han, Zeng, Xin0An. 2014. Texture and Structure Measurements and Analyses for Evad Fillet Freshness Quality: A Review. Comprehensive Reviews in Food Science and Food Safety, Vol,13, pp. 52-62.

Fuentes A., Fernandez-Segovia I. Serra J. Barat J. 2012. Effect of Partial Sodium Replace- ment on Physicochemical Parameters of Smoked Sea Bass during Storage. Food Sci Techno International, Vol. 18, pp. 207217.

Karlsen, Junita D., Krag, Ludvig Ahm., Albertseb, Christoffer Moesgaard dan Frandsen, Rikke Petri. 2015. From Fishing to Fish Processing: Separation of Fish from Crustaceans in the Norway Lobster-Directed Multispecies Trawl Fishery Improves Seafood Quality. Journal of PloS ONE, (10), Hlm. 1-20.

Lauzon, Helena, Margeirsson, Bjorn, Svenisdodttir, Sveninsdottir, Kolburn and Gudjonsdottir, Maria, Martinsdottir, Emilia. 2010. Overview on Fish Quality Research. Impact of Fish Handling, Processing, Storage and Logistic on Fish Quality Deterioration. Skyrsla Matis, Page (1-73).

Honkanen P., Olsen, S.O., dan Verplaken, B. 2005. Intention to Consume Seafood the important of habit. Appetite, No. 45, Volume 2, Hlm. 161-168. http://dx.doi. org/10.1016/j.appet.2005.04.005. PMid: 16011859.

Schiffman L.G. dan Kanuk L.L. 2005. Consumer Behavior, 8th edition, Prentice-Hall, USA.

Verbeke, W. dan Vackier, I. 2005. Individual Determinants of Fish Consumption: application of the theory of planned behavior. Appetite, No. 44, volume 1, halaman 67-82. http://dx.doi.org/10.1016/j.appet. 2004.08.006.PMid:15604034.

Wen, Jin. 2016. Comparison of Nutritional Quality in Fish Maw Product of Croaker Protonibea Diacanthus and Perch Lates Niloticus. Journal of Ocean University of China, 15(4):726-730, August 2016. 